Innovaciencia 2019; 7 (2): xxx-xxx

\title{
A comparative study of Timurid mosques with Evolved Gothic Churches
}

\section{Estudio comparativo de las mezquitas timúridas con las iglesias góticas evolucionadas}

\author{
Behnam Sarbakhshian $^{1, *}$, Mehri Zhianpour ${ }^{2}$
}

How to cite this paper: Sarbakhshian. B., Zhianpour. M. A comparative study of Timurid mosques with Evolved Gothic Churches. North khorasan, Iran. Innovaciencia. 2019; 7 (2): xxx-xxx. DOI: http://dx.doi.org/10.15649/2346075X.762

Received: 11 February 2019/ Accepted: 24 April 2019/ Published Online: 25 October 2019

\begin{abstract}
Considering the wealth of glorious religious buildings in the Timurid period in Iran, which was contemporaneous with the Evolved Gothic period in Europe, a comparative study has been undertaken to explore the architectural effects of these two periods on each other along with their similarities and differences. This is an applied historical research that adopts a library research method for data collection. By studying the political, economic, and cultural conditions of these periods and by reviewing five important buildings belonging to each period, the similarities and disparities of these two architectural styles are investigated to shed further light on the interaction of the Timurid and Evolved Gothic architecture. Despite the geographic distance, and religious and culture different between the Timurid period in Iran and the Evolved Gothic in Europe, which overshadows the interaction of these two periods, one can still witness that the religious architecture of the Evolved Gothic period has been inspired by Timurid architecture in some respects, including building materials, interior decoration of buildings and architectural style.
\end{abstract}

Keywords: Comparative study, Timurid, Evolved Gothic, Architecture

\footnotetext{
Corresponding author: Behnam Sarbakhshian

Email: B.Sarbakhshian@ub.ac.ir

${ }^{1}$ Academic staff of Department of Art and Craft, Faculty of Art, University of Bojnord, North khorasan, Iran

2 Department of Art and Craft, Faculty of Art, University of Bojnord, North khorasan, Iran

zhianpourm@gmail.com
} 


\section{Innovaciencia}

\section{INTRODUCTION}

The study of various historical periods illustrates the close link between art, particularly in architecture, and politics and economy of societies, considering that the slightest change in the political and economic situation of a society also affects its art and architecture. The Timurid and Evolved Gothic eras are no exception to this rule and the study of arts and architecture of these two periods suggests that political and economic conditions of the society are directly related to the art and architecture of these periods.

Therefore, to investigate art in these two periods, it is necessary to explore other critical social factors in order to gain deeper insight into their art. For this reason, in this research, which conducts a comparative study of the religious architecture of the Timurid and Evolved Gothic period, first the eco-political situation and culture of societies in these two eras are explored before looking at their religious architecture. The general understanding of the situation of the societies in question allows a comprehensive analysis of the religious architecture in these eras. Considering that the Timurid period is one of the most prominent Islamic eras in Iran, and artistic forms have blossomed dramatically during this period, it is essential to conduct comprehensive studies in these periods. Therefore, influential forms of arts should be identified along with other factors contributing to their progress in the historical period should be analyzed.

The Timurid period in Iran was contemporaneous with the Evolved Gothic period in Europe. This is also one of the most important periods in European art and even the world. To explore the impact of these arts on each other, it is essential to perform a comparative study between arts in Timurid and Evolved Gothic eras. The selection of religious architecture in this study was primarily motivated by the fact that both periods are characterized with several renowned religious monuments. The research also aims at exploring the similarities and differences of religious buildings constructed in these two eras. To this end, questions such as the "How religion and faith have been illustrated in the architecture of these two periods?", and "What is the impact of these historical periods on construction of religious buildings?" are proposed. Based on an overview of the works remaining from these periods, it can be assumed that similar features of the architecture of Timurid and Evolved Gothic periods, including their focus on the external design of buildings, the construction of lavishly decorated religious buildings and emphasis on the religious architecture, represent the mutual impact of these two periods on each other.

To test this hypothesis and to answer the questions raised, several important buildings founded in this period have been investigated. Given the multitude of buildings constructed in these two periods, five outstanding and renowned buildings were chosen for the study. The selected mosques from the Timurid period include Kabud Mosque in Tabriz, Bibi Khatam Mosque in Samarkand, Goharshad Mosque in Mashhad, Mirchakhmagh Mosque in Yazd and Maulana Mosque in Taibad. Tthe churches chosen from the Evolved Gothic period include the Chartres Cathedral, Amiens Cathedral, Sainte-Chapelle Cathedral, Reims Cathedral and Beauvais Cathedral all in Paris.

\section{RESEARCH QUESTIONS}

1) How has religion and faith manifested in the architecture of the Timurid and Evolved Gothic periods?

2) What are the reasons for popularity of religious buildings during the Timurid and Gothic eras? 


\section{Innovaciencia}

3) What are the similarity and differences between the Timurid and Evolved Gothic architecture?

4) What are the reasons for magnificence and exuberance of buildings in the Timurid and Gothic era?

5) What is the underlying cause of difference between the decoration of buildings in the Timurid and the Evolved Gothic period?

\section{Hypothesis:}

The resemblances of architectural features between Timurid and Evolved Gothic period, including elaborate exterior design, construction of various elaborately adorned religious buildings, and emphasis on religious architecture suggest the impact of these two periods on each other.

\section{Objectives of the Research:}

1) Investigating the resemblances and differences of religious buildings built in the Timurid and Evolved Gothic periods

2) Discovering the reason for construction of abundant and renowned religious buildings in the both periods

3) Studying the reasons for elaborate decorations in construction of buildings in both periods

4) Investigating the effects of religion and faith on the religious architecture of buildings in the Timurid and Gothic periods

5) Comparing the motifs used in the decoration of the mosques in Timurid era and churches in the Evolved Gothic period

\section{Sampling and Statistical Population:}

In this research, given the diversity of architectural works in both Timurid and Gothic periods, five buildings from the Timurid period, and five structures from the Evolved Gothic, which are among the most prominent and decorated buildings of their respective era, were chosen for the study. Five selected mosques from the Timurid period include Kabud Mosque in Tabriz, Bibi Khatam Mosque in Samarkand, Goharshad Mosque in Mashhad, Mirchakhmagh Mosque in Yazd, Maulana Mosque in Taibad. The churches selected from the Evolved Gothic period are Chartres Cathedral in Paris, Amiens Cathedral in Paris, Sainte-Chapeli Cathedral in Paris, Reims Cathedral in Paris and Beauvais Cathedral in Paris.

\section{Data Gathering Method}

The data were collected using library research method. For this purpose, a variety of techniques such as source analysis, image reading and note taking were utilized along with Internet-based resources.

\section{Data Analysis Method}

The probability method was used for data analysis and collected information was analyzed against existing documents and qualitative findings. Given that this is a descriptive and applied research, the analysis was conducted manually based on logical and intellectual reasoning. 


\section{Innovaciencia}

\section{Type of Research}

This is an applied research, which falls in the category of descriptive-historical studies in terms of its nature and method.

\section{RESEARCH BACKGROUND:}

1) The Art of Iranian Architecture during the Timurid Period, Yaghoub Daneshvast, Asar Journal,1, 1980

2) Architecture in Timurid era. Mehrangiz Mazaheri, Jelveh Honar Journal, 8 and 9, 1997

3) Gothic Architecture: History and general features of Gothic architecture. Alireza Seyyed Ahmadian, Quarterly of Architectural Art, 1, 2006

4) The masterpiece of Timurid architecture. Reza Tadbiri Roodi, Payam-e Mobandes Bimonthly, 2006

5) The manifestation of solidarity in the grand mosques of Timurid era. Fatemeh Aghcheloo, Mahe Honar, 120,2008

6) The aspects of Timurid architecture in Central Asia. Robert Hillenbird, Translated by Davood Tabatabaee, Golestan-e Honar Journal, 14, 2008

7) Romantic Architecture, Gothic Architecture. Zahra Davoodi, Tafakor-e Memari, 25, 2011

8) Adaptation of decorative motifs of the Timurid era architecture in the works of Kamal al-Din Behzad. Mahnaz Shayesteh Far and Fatemeh Sadra Nashin, Negare Journal, 25, 2013

\section{Geographical, Historical, Political and Economic Situations in the Timurid Period}

The Timurids or Gürkaniyan (Mughal Empire) in Iran ruled in the period of 771-911 AH (150-670 AD) (Razi, 1962). Initially, the boundaries of the Timurid rule stretched all the way across Central Asia and then throughout Khorasan, and then to all parts of Iran, Ottoman, and as far as India. Timor succeeded in conquering Anatolia and Mesopotamia by means of his massive troops and heavy attacks. (Blair and Bloom, 2003). The overall picture obtained from the architecture and urban development of the Timurid era represent a great boom, especially in the early fifteenth century, with limited but exorbitant revenues in the last half of the century. The outflow of war booties from rich and distant lands like India pumped a fresh blood in the vessels of the Samarkand economy. In the Timurid era, silk trade with Asia was established itself as a key factor (Wilber and Glomback, 1995). During the Timurid period, Iran was overwhelmed with endless wars. The ruling classes in each city built strong citadels to both stand against the threat of a foreign invasion, and to protect their foreign agents against the local population (Wilber and Golmaback, 1995).

\section{Cultural, Artistic and Social Status of the Timurid Period}

During the Timurid era, the government relied on the Islamic laws, and the official religion of kings and princes of Timurid was Sunni Hanafi. This period is also characterized with the emergence of Shiite-Sufi 


\section{Innovaciencia}

movements. During the Timurid period, despite a myriad of domestic and foreign wars, mass murders, looting, instability and compromised security, society was thriving in the realm of science and literature. It was primarily driven by the support and accolade of the master of knowledge and science by kings and princess of Timurid.

There were plenty of schools and centers of education in the Timurid period. One of the notable features of the Timurid era was the high status of women in society, and during this period, religion overshadowed various aspects of social life (Mir-Ja'fari, 2000). "During the rule of Timurids, as in Ilkhani period, architecture and the art of manuscript illustration took precedence over other forms of art" (Hillenbird, 2006: 211). This period is regarded as the era of flourishing painting, decoration, gilding and calligraphy, and all other aspects of preparing a book (Mirjafari, 2000). The golden age of miniature began during the Timurid era in Herat by the artists of that time. The strong and solid connection of Herat court and the Ming Dynasty in China heightened the influence of Chinese art in Herat's art school (Mirjafari, 2000).

The creation of an Iranian style of paintings that gradually dwindled foreign influences was inspired by the Herat Painting School (Damand, 2004). The writers, especially the poets, enjoyed a high status in the court of Herat. Under the rule of Sultan Hussein Bayghara, his court became the capital of culture in the east of Islamic world (Wilber and Golmbak, 1995).

\section{General Features of the Timurid Era}

One of the main features of the Timurid architecture is its magnificent and exuberant buildings that are unparalleled not only in the Central Asia, but also in the east of the Muslim world (from Turkey to India). Hence, glorious buildings whose design and architecture have been inspired by Timurid style are found in vast areas across the Muslim world. The abundance of such splendid buildings in the Timurid era as the capital of this powerful emperor led to the advent of a royal architectural style that set the example for other areas and even later periods (Blair and Bloom, 2003).

Architectural style in the Timurid period was inspired by Azeri style (Pirnia, 2004)

Utilization of local sizes and scales in replicating the map of buildings (Blair \& Blum, 2003: 61)

The main lines in the facades often stretch without interruption, and these vertical and parallel lines extend as far as domes to highlight the buildings.

The domes are oblongated and their pillars are long

There are majestic entrances and porches

Vaults that stretch across two floors without interception

Decorations that have been executed independent of the building framework

The presence of rectangular weights over the entrances

The execution of woods to accentuate covered sections (for acceleration)

Stretching main arches of covers under the dome (to accentuate the height of ceiling) 


\section{Innovaciencia}

Using an element called squinch or "narrow round filling" which is extended to the roof, transforming the square plans into octagons that foregrounds the height of ceiling.

Using Kelil or large arches for short covers

The presence of Turkish star-shaped cover on the shaft of vaults in dome-free ceilings

The dominance of shades of azure in tile decoration

Using formalization in ceiling covering

Using prominent façade and exterior appearance in most cases

Using arches formed by the intersection of two ovals with a cusp higher than half of the arch span

The presence or remainders of golden hue in the decoration of painting and tiling

The special designs in tiling, plastering and painting, such as the use of slabs or gratings with hexagon designs in tiles (Mir-Ja'fari, 2000)

Introduction of squinch vaulting system as one of the major innovations of the Timurid architecture" (Blair \& Blum, 2003: 72)

The construction of "double-shell domes" flourished in the late Timurid period (Goshayesh, 2000)

\section{Decorations Used in Buildings of Timurid Period}

The use of marquetry tiles, tiles with floral designs, or mosaic tiles (which is a feature of the architectural decoration of this period, with the tiling work reaching its zenith)

Simultaneous use of bricks, tiling and plastering in a building

Special decorations of the altar (decorations of the altar including plaster, brick, tile, tile-decorated bricks, stone, wood)

Muqarnas

Murals and wall paintings (in Timur's palaces, mansions and gardens)

Delicate plaster decoration

\section{Famous Mosques Constructed in the Timurid Era:}

Goharshad Mosque in Mashhad

Bibi Khatam Mosque in Samarkand

Kabud Mosque in Tabriz

Mirchakhmagh Mosque in Yazd 


\section{Innovaciencia}

Maulana Mosque in Taibad

\section{Features of Some Mosques Built in the Timurid Era}

\section{Kabud Mosque in Tabriz.}

The only remaining building from Qarqquyonlu era is the Kabud or Turquoise Mosque in the capital of their ruling, Tabriz, which was built in the year 1465 AD (869 AH). (Blair and Bloom, 2003: 78). "The mosque with its unique architecture and decoration is known as Turquoise Mosque for its blue mosaic tile covering. The main entrance of the mosque is an excellent example of tiling decoration. In these tiles, a variety of colors including dark blue, gray, and meadow green have been used. Some of the decorations applied in this mosque include glazed mosaics with blue being the dominant decorative colors in this mosque. The inscription marquetry is a prominent instance of marquetry in the Islamic period (Fig. 1). The mosque, lacking a porch and central courtyard, is essentially a part of a complex of various buildings, including water reservoirs, library, tombstones and Khanqahs for the Sufis. Since this mosque was built on the order and patronage of Abu Mu'zafar Jahan Shah, it is known as the Mu'zafarieh Mosque. What adds to the grandeur and magnificence of this mosque's decoration is its mellow Arabesque designs, which are often executed in white or golden colors on navy blue with green background of glazed tiles. A row of shell-like or golden tiles has been executed at the base of chain framework of the entrance. This tiling style is one of the rarest decorative techniques in architecture of the 15 th century "(Blair \& Bloom, 2003: 80-78).

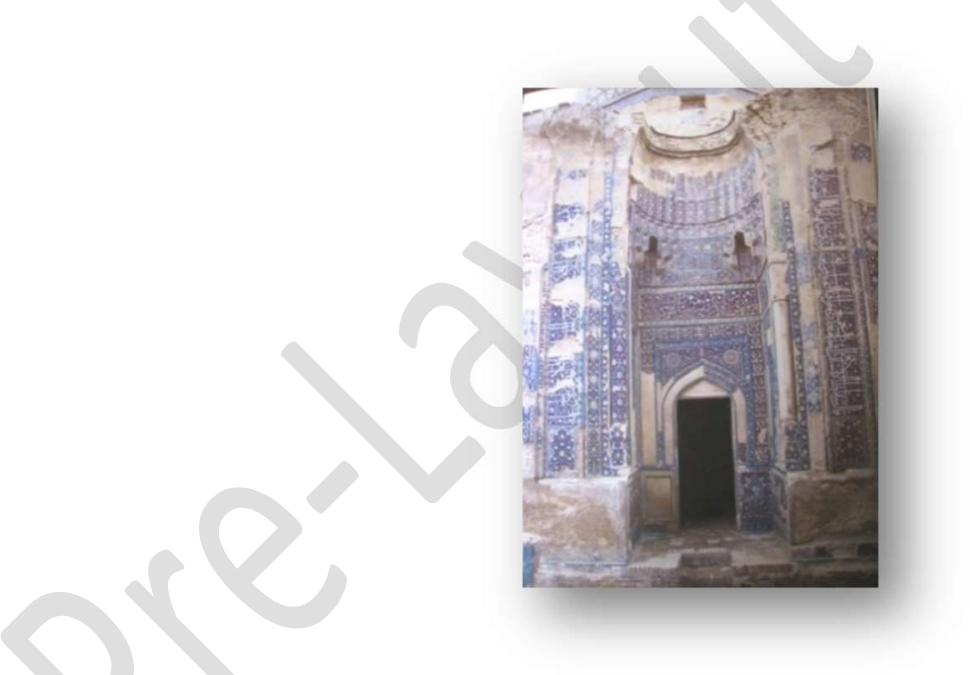

Fig 1 - Kabud Mosque of Tabriz (Blair \& Bloom, 2003.66)

\section{Bibi Khatam Mosque in Samarkand}

In $1399 \mathrm{AH}$, Timur ordered the foundation of a grand, luxurious, and magnificent mosque in his capital, Samarqand, which was unparalleled in its vastness and glory. The building was constructed in a rectangular area, with towering minarets on high vault of its entrance porch. The walls of this mosque are decorated with tiles and mosaic bricks, and the domes are covered with blue-glazed tiles, which exhibits the fine and diverse decorations of Timurid era (Fig. 2). The proportion of sizes in this mosque 


\section{Innovaciencia}

has been preserved in the design of other Timurid buildings as well. The design and decoration of this grand mosque, which was built upon the order of Timur, was not only intended to safeguard the tradition of the court of the Ilkhans, namely the construction of exuberant mosques, but also to celebrate the power and conquests of Timur. The construction and decorating process of this mosque was so important that one century later, Behzad, one of the renowned Iranian painters, portrayed this mosque. (Blair and Bloom, 2003).

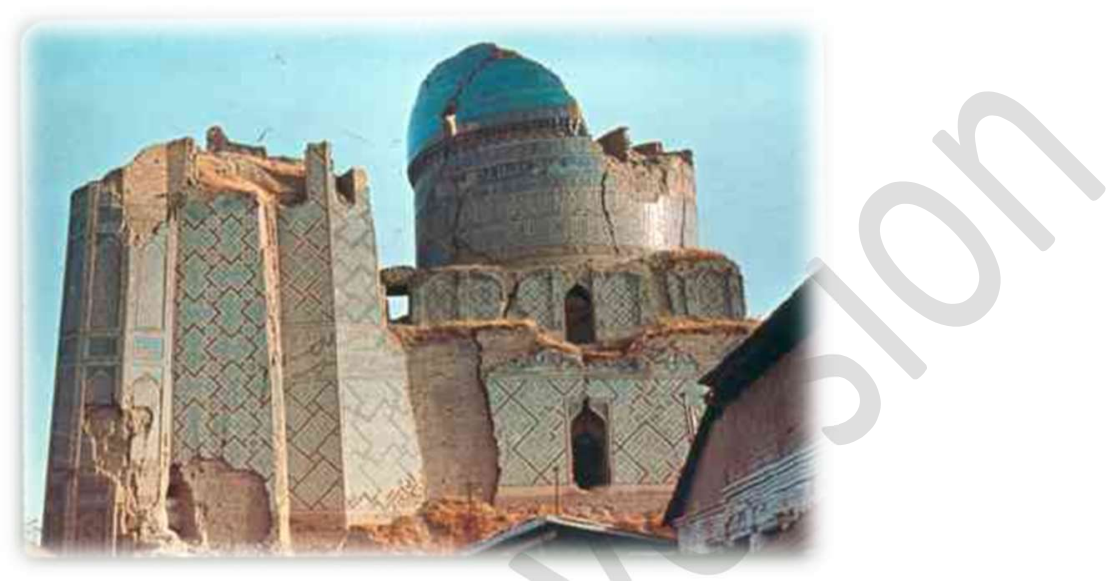

Fig 2 - Bibi Khatam Mosque in Samarkand (www.cgie.org.ir)

\section{Mirchakhmagh Mosque in Yazd}

"The largest complex built during the Timurid period is a cluster consisting of a four-porch mosque, a Khanqah, water reservoir and a well adjacent to the bathroom and the caravanserai that supplied their required water. This complex was established by the order of Mirchakhmagh, the ruler of Yazd during the reign of Shahrokh with the patronage of his wife. In the structures built during the Timurid period in these areas, local architectural styles are notable. Despite the light, elegant and intricate materials used by the Timurid architects in the buildings of grand cities such as Herat, in the structures of these areas, heavy and bulky materials have been utilized and there is no sign of vaulting characteristic of crossing arches and vaults of the Herat School (Figure 3). The walls are usually covered with slurry and white plaster, and only the base including plinth and pulpits are decorated with the tiles "(Blair and Bloom, 2003: 75 and 76). 


\section{Innovaciencia}

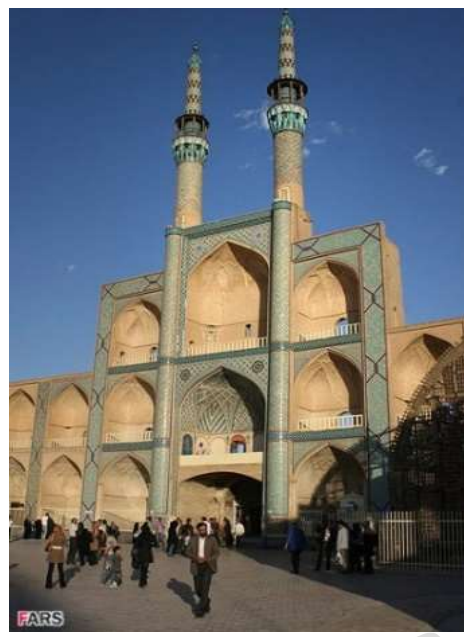

Fig 3 - Mirchikmaq Mosque in Yazd (Blair \& Bloom, 2003.77)

\section{Goharshad Mosque in Mashhad:}

Goharshad (Shahrokh's wife) ordered the erection of an immense mosque and two large halls for public gatherings called Dar al-Siyadeh (house of Sadat) and Dar al-Hofāz (home of the reciters of the Quran) next to the shrine of Imam Reza (AS). Qavam al-Din Shirazi, the eminent architect of the time, built the mosque based on the traditional Iranian four-porch model. However, in this building, there is a dome over the front porch that faces the direction of Kaaba, and the rectangular hall of Dar al-Hofaz is covered by a vaulting structure (Fig. 4). The decorations of Goharshad mosque consisted of costly ornaments that were executed over a long time. There are two strands of fine tiling as an uninterrupted margin all across the walls in the mosque courtyard that surrounds the mosque and its neighboring complex. On both sides of the Qibla porch, there are two minarets adorned with fine tiles of diamond-shaped patterns and a large inscription on their top that magnifies the glory of the porch. Behind the Qibla porch, there is a large mihrab embellished with mosaic tiles and mogharnas that hang in form of a cascade of crescent arches. The decorations of this mosque are genuinely magnificent (Wilber and Golmbek, 1995).

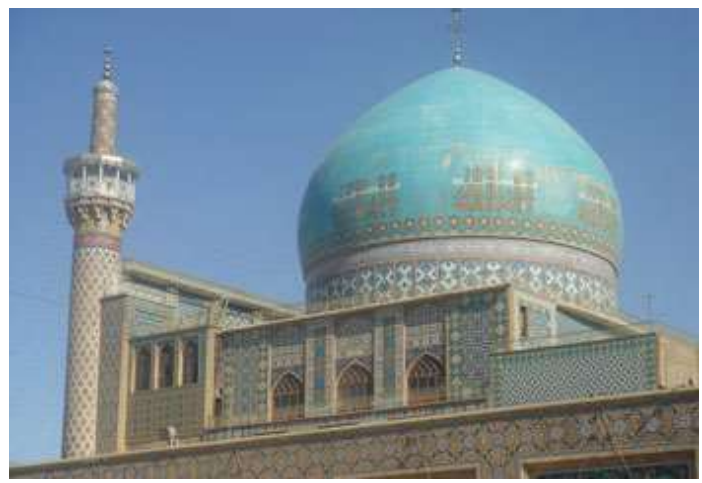

Fig4 - Goharshad Mosque in Mashhad (www.exoticindia.art.com) 


\section{Innovaciencia}

\section{Maulana Mosque in Taibad:}

A majestic monument inherited from the time of Shahrokh Timurid, this mosque and the tomb of Maulana Sheikh al-Din Khafi, a mystic of the Timurid era, were built in the city of Taibad. It is considered one of the most prominent monuments of the Shahrokh era, with some comparing it to Goharshad Mosque in Mashhad. In general, the significance of this building is due to its stoning historical inscriptions and the tiling of its entrance and porch. The features of this monument and its invaluable mosaic tiled decorations are representative of architecture in Timurid period (Blair \& Bloom, 2003) (Fig. 5).

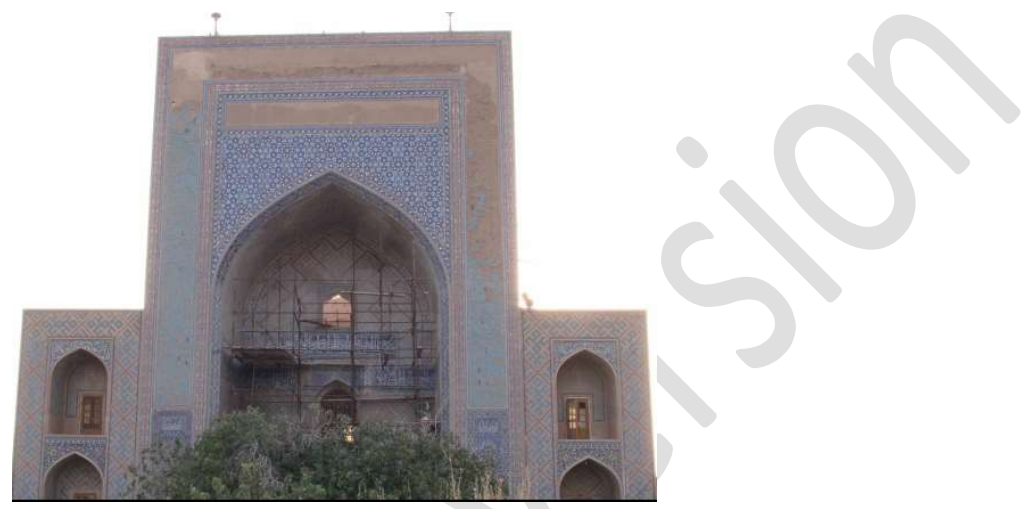

Fig 5- Maulana Mosque in Taibad (www.trendir.com)

\section{Geographical, Historical, Economic, and Political Situations in the Evolved Gothic Period:}

The origin of Gothic art can be traced back to France and the spread of Gothic art to areas like the Rhodes Islands Cyprus, and other parts of the Middle East should be sought in the military, commercial and religious activities of Western Europeans in the Mediterranean. (Crandel, 2006). The Gothic period lasted from the mid-12th century to the first decades of the sixteenth century.

-Early Gothic from 94-1140

- Evolved Gothic from 1144-1300

- Late Gothic from 1300 to the 16th century (Gardner, 1986)

The twelfth century was characterized with the expansion of Europe, population boom and the improvement of agricultural and commercial methods, and the thirteenth century saw the economic boom and the development of the textile industry - which was the culmination of economic growth.

\section{Cultural, Social, Artistic and Literary Situations in the Evolved Gothic Period:}

"The official religion in the Gothic period was Christianity and Catholicism. Different sects emerged in this period, including Franciscan and Dominican sects, which reached their peak during the thirteenth century. The thirteenth century, representing the victory and conquest of the Popes, marks the successful blending of religion, philosophy and art as well as the early stages of development and consolidation of states that later founded the historical pillars of the new age."(Gardner, 1986: 316)." In the Gothic society, 


\section{Innovaciencia}

women assumed a more important role, and the expression of love for women in arts was praised and recognized"(Gardner, 1986: 314). Universities at this time acted as key educational centers and the progression of scientific discoveries was shaping the first Renaissance waves in Europe (Gardner, 1986). In a short time, the emerging Gothic architecture blossomed, transforming into an art form that portrayed the greatness and glory of the French royal family. The Gothic style is not exclusive to the architecture, and there are even countless objects and sculptures made in this way. The use of the term Gothic was inspired by pointed arches, tiled vaults and their lavish decoration and ornaments that were characteristic of this architectural styles (Crandle, 2006). The gothic art was a product of Christians' faith, and its purest manifestations can be found in architecture and churches, and then in other arts, such as sculpture and book design in Gothic periods. In the 13th century, the illustration of manuscripts in Byzantine style emerged and continued in the 14th century. Schools, churches, and royal families were in need of books with religious or non-religious subjects (Bracones, 2002). Gothic literature is closely associated with Gothic architecture. This literary genre was mainly adopted to describe high-rise buildings in Gothic styles as well as ancient and ruined castles, monasteries and monuments (Goshayesh, 2000). This architectural component has been masterfully incorporated in the western church buildings with high Gothic windows painted by rose flowers and vertically painted windows in sections such as altars. "Each window with a painted glass like the Bible can be considered as an independent unit" (Dornyei, 2011: 12).

\section{Architecture and Decorations in the Evolved Gothic Period:}

"Architecture in this period is divided into two categories:

1) Religious architecture (church and schools)

2) Non-religious architecture (royal palaces and mansions and regal residences)

The most outstanding illustration of Gothic art are magnificent cathedrals, which are often built in the centers of major cities "(Vaziri, 1984: 306).

The thirteenth century is the era of grand cathedrals, which were built with the contribution of artists from almost all disciplines. Basilica churches were distinguished with statues at their entrances and colored glasses (Crandle, 2006).

\section{Typical Features of the Gothic Age:}

Use of vaults and arches in the cathedrals

A feature of Evolved Gothic is that by designing the porch, more light was brought in through a series of large windows mounted under the vault into the hall.

The interior of churches was dark due to the application of colored and painted glass in windows

The emphasis on vertical designs and transparency can be observed in the evolution of design in a progressive Gothic style. The flood of light that shines through windows below vaults magnifies their vastness.

Use of local stones in construction 


\section{Innovaciencia}

In the Evolved Gothic period, space organization was highly important.

Height, narrow grooves, thin walls, elongated towers and minarets and pointed tip of minarets are among other features of Evolved Gothic architecture.

Use of suspended buttresses

Rotating windows and colored pointed arches

Use of cross-shaped plans in the structure of churches

The integrity of the interior design and fascination with the decorations of new vaults

Importance of interior decorations and ornaments in buildings

Emphasis on the exterior of buildings

Advances in the arching technique

The continuity and organic trend of the interior in an Evolved Gothic style. With the new design applied to the courtyard wall, more light reached the courtyard, which foregrounded the structure in the eyes of spectators.

The emergence of the "pompous" style in the first half of the thirteenth century, which had a huge impact on Evolved Gothic architecture (Gardner, 1986).

\section{Decorations in Evolved Gothic Architecture:}

Use of stained glass in decorating church windows

Use of murals and wall paintings in the interior decoration of churches

Embellishment of the altars using sculptures made of stone or alabaster, which is most commonly found in Spain.

Use of sculptures (loqazi statutes) in the decorations of buildings

Surface decorations and stone perforation

Applying bas reliefs of saints on the arches of the entrance ports (Bracones, 2002)

\section{Famous Churches Built in the Evolved Gothic Period:}

Chartres Cathedral in Chartres, France

Amiens Cathedral in Paris

Sainte-Chapelle, Cathedral in Paris 


\section{Innovaciencia}

Reims Cathedral in Paris

Beauvais Cathedra in Paris

\section{Features of Cathedrals Built in the Evolved Gothic Period:}

In the Christian churches, like many other places of worship, people light candles hoping that their prayers are answered. "The burning candles remind us that our souls are constantly in the presence of God and His saints. Candles, which are usually lighted on the behalf of other people, prove that the worshipers are not self-centered and reliant on the God "(Anderson, 2003: 8)" When the worshipers enter the church, some candles in the candlestick are lighted for the living and some for the deceased relatives. However, if any of the living relatives is badgered by a problem, it is recommended to light a candle for everyone. Candlelight should be accompanied by the words of prayer. By lighting candles, we plead for God's blessing and support for the living, divine forgiveness and eternal salvation for the departed "(Vernikos, 2013: 4). The songs and music played in the church during the praying ceremony can affect the morale of the worshiper. "The holy music is in a sacred linkage with the act of praying, which invigorates the prayers, promotes the unity of mind, and grants a more pleasant to the religious ceremony. This sanctity, embraces religious and spiritual dimensions, both of which should be considered in the cultural context "(USCCB, 2007: 65).

\section{The Chartres Cathedral}

The most brilliant symbol of the "Great Gothic" is the French Cathedral with its colored glass and decorative sculptors. It is believed to be the first cathedral to use suspended or braided buttress (Helen Gardner, 1986). "In the Chartres Cathedral, almost all of its original colored glasses have been preserved, and the colored and stained glasses, while rendering the interior darker, brings a stunningly colored light to the church, which has made this cathedral a haven for the admirers of Gothic architecture" (Gardner, 1986: 326). The interior design of the church is deceptively austere. The Chartres Cathedral is not only high, but also projects elevation, which is mostly due to the sharp protrusion of columns (Fig. 6). The colored glasses of the Chartres Church convey a sense of coordination and mystery to the viewer, and navy blue and bright red have been used in its painting The Chartres church looks far more majestic from the outside. The large thickness of its walls is demonstrated by the shades of window. The both sides of gates are occupied by loqazi sculptors, which are similar to sculptural columns but free standing (Crandle, 2006). "The entire Cathedral floor is covered with marble mosaics, which is decorated with subtle visual expressions of Sibyl, scenes of the Bible, piety and parables" (Carli, 2015: 32. 


\section{Innovaciencia}

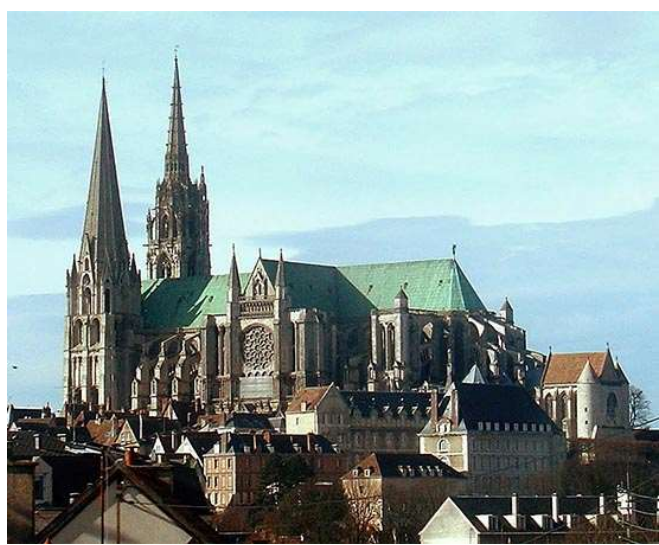

Fig 6 - Chartres Cathedral (www.wikipedia.com)

\section{Amiens Cathedral:}

The façade of Amiens cathedral transcends its exterior decorations in terms of richness and complexity of its superficial models. Despite its delicateness and elegance, the church facade has preserved its grandeur and is one of the first fronts to be fully integrated with its adjacent building (Figure 7). The architectural map of the Amiens Church, like its façade, is representative of an Evolved Gothic style. The blueprint is probably taken from the Chartres Cathedral and its dimensions are even more delicate. Other features of this cathedral include:

1- Quadrilateral blocking techniques

2. Square-framed gable vaults

3. A buttress grid that enables relatively complete breakdown of heavy objects and thicker Romanesque walls.

4) The vaults dedicated to the choir, as shown in the following figure, resembles the sky, which is hung from a set of columns like the roof of a tenet.

The light that floods through the windows under the vault accentuates the height of vaults (Gardner, 1986). 


\section{Innovaciencia}

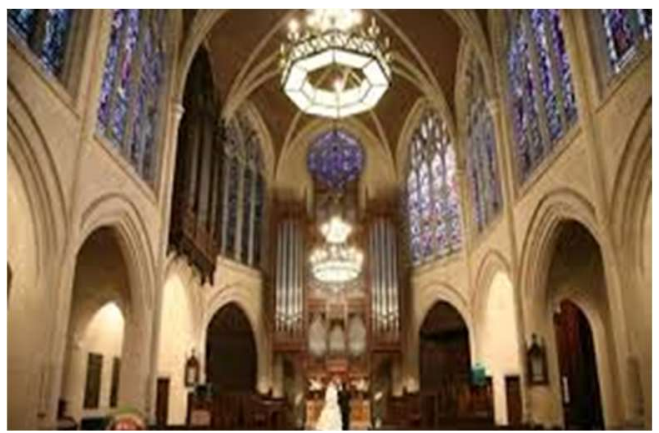

Fig 7: Interior of Amiens Cathedral (www.wikipedia.com)

\section{Reims Cathedral in France:}

"The fully-fledged and developed Gothic style appears on the western portals of the Reims Church, which were built in the mid thirteenth century. At first glance, statues on Loqaz seems to be free-standing structure independent of the architectural background. These sculptors belonging to the Reims Cathedral, the predecessors of which in Chartres Cathedral are even more pointed, creates an immediate tension in the overall framework of the interior "(Gardner, 1986: 332). The pillars of the main vaults are designed to accentuate the height of the Reims. The royal grandeur of this architectural monument is fitting for a church, where the French kings were anointed and entrusted with power (Fig. 8). The harmony and order are also distinctive features of the western design of the Reims Cathedral. The Reims façade is composed of three entrances leading to the main hall of the church, sculpted loqaz and multi-streak arches, a floral window above the middle entrance and twin towers without a conical minaret as well as horizontal and vertical divisions on its front. The Reims façade appears to have a three-dimensional meshed structure infused with pointed shapes. Its three entrances even have two extra pediments on both sides (Crandle, 2006).

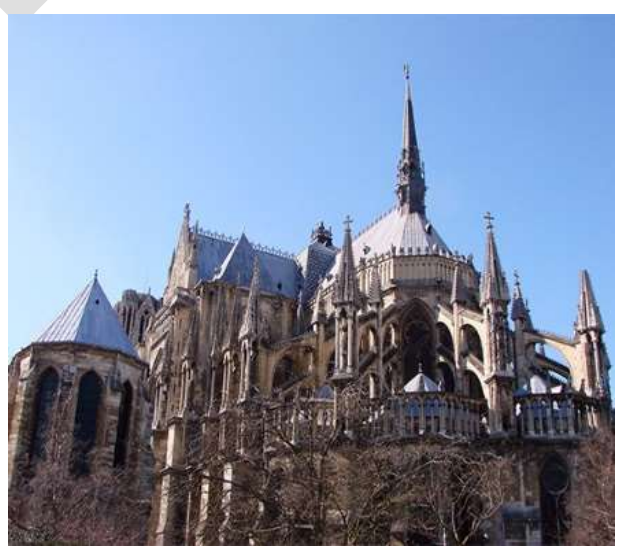

Fig 8- The Reims Cathedral (www.wikipedia.com) 


\section{Innovaciencia}

\section{The Sainte-Chapelle Cathedral in Paris:}

"A spectacular and distinctive example of pompous style is the Sainte-Chapelle Cathedral in Paris. In this church, the diminishing of walls and shrinkage of column continue to the point that about three quarters of the entire building is covered with stained glasses. Amidst multicolored stone surfaces and glittery strips of decorative mosaic tiles, there are statues of the apostles. Here, we see technical and artistic delicacies that revolutionize the somber harmony and magnificence of art in the beginning of that century. The emphasis on the fineness and elegance of the architectural elements and the linear demonstration with the delicate painting and subtle details of adornments reminding us of decorative boxes of antique objects at that time. Some argue that the main idea behind designing this building was to underscore this remembrance "(Gardner, 1986: 329). "Sainte-Chapelle " was originally embellished with greater decorations and gilded stones. The bas reliefs with golden background resembled the models of metalwork. Outside the building in the space between windows were filled with some sculptures. The factor that reinforces its correspondence to the magnificent alms boxes was the glamour of colored glass that spreads all the way across the distance between vertical pillars (Fig. 9). There are tall and thin windows with innovative grid designs (Crandle, 2006).

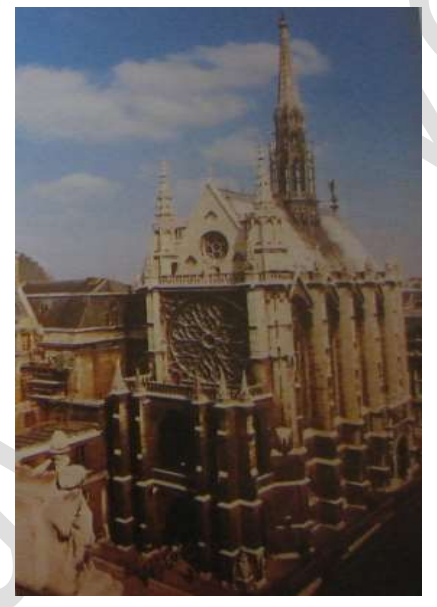

Fig9- Sainte-Chapelle Cathedral (Crandle, 2007,88)

\section{Beauvais Cathedral in Paris:}

"The choir stand in the unfinished Beauvais Cathedral is the embodiment of Gothic invasion into the skies. The ascendance towards sky, which first appeared on top of Sainte-Chapelle hall in Paris, fascinated a generation of future Gothic architects. Assisted with new stone frameworks, they strived to achieve goals that deemed unreachable. Using finer columns, they managed to set new records for high-rise structures, and their goal was to illustrate perceptible images that were beyond the reach of ordinary men. There was a large space between pillars and the main buttress wall was extremely delicate. The choir stand was reconstructed with a greater consistency. There were intermediate pillars with hexagonal vaults built in the traditional style. The far pillars and subtle buttresses possessed the same features that architects adherent to pompous style, while striving to mold architecture out of nothing, were among its advocates too, "(Gardner, 1986: 330) (Figure 10). 


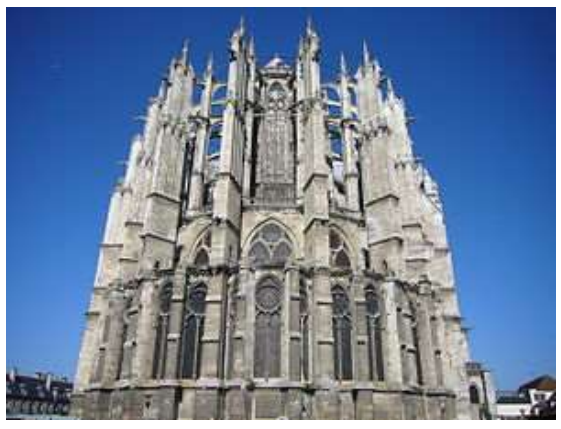

Fig10 -Beauvais Cathedral (www.wikipedia.com)

\section{RESULTS AND DISCUSSIONS}

\section{Correspondence in Cultural and Social Status:}

Table 1 - Correspondence in cultural and social status

\begin{tabular}{|l|l|}
\hline Timurid & Evolved Gothic \\
\hline The emergence of Shiite-Sufi movements & $\begin{array}{l}\text { The rise of various sects, including Franciscans and } \\
\text { Dominicans }\end{array}$ \\
\hline Multiple civil and foreign wars & Civil wars between different sects \\
\hline Underlining the women's position in society & $\begin{array}{l}\text { The expression of the importance of women and the } \\
\text { love of women in arts }\end{array}$ \\
\hline $\begin{array}{l}\text { Dominance of religion and faith in different } \\
\text { aspects of life }\end{array}$ & Dominance of religion and faith in art and architecture \\
\hline Growth of schools and educational centers & Universities turning into major educational center \\
\hline $\begin{array}{l}\text { Flourishing of progressive scientific and } \\
\text { literary works }\end{array}$ & Advances in scientific discoveries \\
\hline
\end{tabular}

\section{Differences in Cultural and Social Status}

Table 2- Differences in cultural and social status

\begin{tabular}{|l|l|}
\hline Timurid & Evolved Gothic \\
\hline The official recognition of Islam and Hanafi religion & Samarkand is the capital of the government \\
\hline Christian and Catholic religions are practiced & Paris is the capital of the government \\
\hline
\end{tabular}

\section{Correspondence in Political and Economic Status}


Table 3 - Correspondence in political and economic status

\begin{tabular}{|l|l|}
\hline Timurid & Evolved Gothic \\
\hline Big economic boom & The peak of economic development \\
\hline Agricultural development & Improved agricultural techniques \\
\hline The wars and invasions of Timor & The internal conflicts between the church and the government \\
\hline
\end{tabular}

\section{Correspondence in Art and Literature}

Table 4 - Correspondence in art and literature

\begin{tabular}{|l|l|}
\hline Timurid & Evolved Gothic \\
\hline $\begin{array}{l}\text { The supremacy of architecture and manuscript illustration } \\
\text { over other arts }\end{array}$ & $\begin{array}{l}\text { The pinnacle of architectural } \\
\text { flourishing }\end{array}$ \\
\hline The growth of painting and other realms of publishing & $\begin{array}{l}\text { Paris as the center of manuscript } \\
\text { production }\end{array}$ \\
\hline
\end{tabular}

\section{The Differences in Art and Literature}

Table 5 - Differences in Art and Literature

\begin{tabular}{|l|l|}
\hline Timurid & Evolved Gothic \\
\hline The effect of Chinese rt (Ming) on Herat School & Illustration of manuscripts in Byzantine style \\
\hline The golden age of miniatures & Blossoming of sculpturing art \\
\hline The separation of literature and architecture & $\begin{array}{l}\text { The close relationship between literature and } \\
\text { architecture }\end{array}$ \\
\hline
\end{tabular}

\section{Correspondence in Architecture:}

Table 6- Correspondence in architecture

\begin{tabular}{|l|l|}
\hline Timurid & Evolved Gothic \\
\hline The creation of regal architectural style & $\begin{array}{l}\text { Architecture as a vehicle for representing the royal } \\
\text { family of France }\end{array}$ \\
\hline Magnificent and exuberant buildings & Majestic cathedrals \\
\hline $\begin{array}{l}\text { Accentuating the height of buildings using } \\
\text { vertical lines }\end{array}$ & Emphasis on verticality and transparency \\
\hline Stretched shape of domes & Stretched shape of minarets and towers \\
\hline High base of domes & Tall and pointed minarets \\
\hline $\begin{array}{l}\text { The importance of the façade and external } \\
\text { appearance of buildings }\end{array}$ & Emphasis on the external appearance of a building \\
\hline Progress in the arching style & Progress in the arching style \\
\hline
\end{tabular}




\begin{tabular}{|l|l|}
\hline $\begin{array}{l}\text { The existence of a vault or immense arches in } \\
\text { the structure }\end{array}$ & Incorporation of vaults in the structure \\
\hline $\begin{array}{l}\text { Using murals and wall paintings in the } \\
\text { decoration of the palace }\end{array}$ & $\begin{array}{l}\text { Using murals and wall paintings in the interior } \\
\text { decoration of the churches }\end{array}$ \\
\hline Special decoration of mihrabs & Decoration of alters \\
\hline
\end{tabular}

\section{Architectural Differences}

Table 7 - Architectural differences

\begin{tabular}{|l|l|}
\hline Timurid & Evolved Gothic \\
\hline Use of bricks in the construction of buildings & Use of local stones in construction of the building \\
\hline Use of golden and azure designs in decorations & Incorporation of red and green in decorations \\
\hline $\begin{array}{l}\text { The extensive use of tiling in the architectural } \\
\text { decoration }\end{array}$ & Use of stained glasses in decorating the church \\
\hline Fine plaster decorations & Decorating the building with sculptors \\
\hline Use of muqarnas in the structure design & Surface decorations and stone perforation \\
\hline $\begin{array}{l}\text { Mehrab decorations including plasters, bricks } \\
\text { and tiles }\end{array}$ & $\begin{array}{l}\text { Decoration of alters using stone sculptures or } \\
\text { alabaster }\end{array}$ \\
\hline $\begin{array}{l}\text { The absence of sculpture and base reliefs in } \\
\text { buildings }\end{array}$ & $\begin{array}{l}\text { The incorporation of bas reliefs in decoration of } \\
\text { buildings }\end{array}$ \\
\hline Constructing double-shell domes & Gable and pointed roofs \\
\hline Use of rectangular planes & Use of cross-shaped planes \\
\hline
\end{tabular}

. 8. Differences between Select Mosques from Timurid period and Select Churches from Evolved Gothic Period

Table 8 - Differences between selected mosques from the Timurid period and selected churches from the Evolved Gothic period

\begin{tabular}{|l|l|}
\hline $\begin{array}{l}\text { Select mosques belonging to Timurid } \\
\text { period }\end{array}$ & Select churches belonging to the Gothic period \\
\hline Use of tiled decorations in most mosques & Use of stained glass in most churches \\
\hline $\begin{array}{l}\text { Scroll floral and arabesque patterns tiling of } \\
\text { Kabud Mosque }\end{array}$ & $\begin{array}{l}\text { Rose patterns painted in the window of Amiens } \\
\text { Church }\end{array}$ \\
\hline $\begin{array}{l}\text { The dominance of the azure in the tile } \\
\text { decoration of Kabud }\end{array}$ & $\begin{array}{l}\text { Use of navy blue and bright red in the colored glasses } \\
\text { of Chartres Cathedral }\end{array}$ \\
\hline $\begin{array}{l}\text { Crossing vaults in the Goharshad Mosque of } \\
\text { Mashhad }\end{array}$ & Square-framed gable vaults in Amiens Cathedral \\
\hline $\begin{array}{l}\text { Tall and onion-shaped domes in Bibi } \\
\text { Khatam mosque }\end{array}$ & Twin towers without a conic minaret \\
\hline $\begin{array}{l}\text { Use of muqarnas design in Goharshad } \\
\text { Mosque }\end{array}$ & Use of loqazi statues in Chartres Cathedral \\
\hline
\end{tabular}




\section{Correspondences of Selected Mosques from the Timurid Period and Selected Churches from the Evolved Gothic period}

Table 9- Correspondences of selected mosques from the Timurid period and selected churches from the Evolved Gothic period

\begin{tabular}{|l|l|}
\hline Select mosques belonging to Timurid period & Select churches belonging to the Gothic period \\
\hline Glory and magnificence of Bibi Khan mosque & Royal glory and majesty of Reims Cathedral \\
\hline $\begin{array}{l}\text { Use of light, delicate and symbolic materials in } \\
\text { buildings }\end{array}$ & $\begin{array}{l}\text { Emphasis on thinness and delicacy in Sainte- } \\
\text { Chapelle Cathedral }\end{array}$ \\
\hline $\begin{array}{l}\text { Use of crescent vault in the Goharshad Mosque } \\
\text { of Mashhad }\end{array}$ & Use of hexagonal vaults in Beauvais Cathedral \\
\hline The square domed central Shabestan & Square blocking grid in the Chartres Cathedral \\
\hline
\end{tabular}

\section{CONCLUSION}

This research was undertaken to find the essence and foundation of religious architecture in the Timurid and Gothic periods and the following results were obtained:

1) Religion and faith are two major factors influencing the architecture of both periods, so that the art of both periods can be labelled as religion-oriented. This is the main drive behind the popularity of religious buildings in this period.

2) In both periods, the kings and rulers have been the most influential figures in religious architecture, and this impact is more perspicuous during the Timurid period. Considering the growing importance of women in the Timurid period, several mosques were commissioned by a women affiliated with the government.

(3) The two different religions in Timurid and Evolved Gothic periods and the discrepancy of the dominant intellectual spheres is responsible for partial alienation of these two arts, but given the fact that they had a relatively identical culture and economy, their interactions should not be overlooked.

4) The direct support that the kings and ruling authorities showed for the architecture and religious structures built in both periods had a direct bearing on the magnificence and grandeur of religious buildings in these periods. In fact, these buildings were a means to showcase the power of kings in these societies.

5) Arches or immense vaults are characteristic of Islamic architecture evident in the religious buildings of Timurid period, but are not typical architectural element in pre-Gothic era in Europe. However, in the Evolved Gothic period, there is a growing interest in incorporation of arches and vaults in buildings, especially churches, which may have been inspired by the Islamic architecture in the Timurid period.

6) In Islamic architecture and the Timurid period, in addition to the focus on exterior design of a building, special attention has been paid to the interior decoration of building. In churches founded in Evolved 


\section{Innovaciencia}

Gothic era, unlike previous periods, there are lavish and exuberant decorations inside the buildings, and the interior is adorned with the murals, paintings and bas reliefs. It also manifests the influence of Islamic architecture of the Timurid period on Evolved Gothic architecture.

7) The rise of the Azeri style in Islamic architecture and the importance of magnification in this style continues to the Timurid period, and the emphasis on the accentuation of buildings in the Gothic period in Europe is certainly affected by the monuments of Islamic architecture.

\section{REFERENCES}

1. Razi, Abdullah (1962). Complete History of Iran. Edited by Kazem Kazemzadeh Iranshahr, Tehran: Tabesh.

2. Blair, Sheila and Jonathan Bloom (2002). Islamic Art and Architecture. Translated by Yaghub Azhand, Tehran: SAMT.

3. Blair, Sheila and Jonathan Bloom (2003). Islamic Art and Architecture in Iran and Central Asia during the Period of the Ilkhanis and Timurid.

4. Wilber, Donald and Lisa Glambeck (1995), Timurid Architecture in Iran and Turan. Translated by Karmatullah Afsar and Mohammad Yousef Kiani. Tehran: Heritage Organization of Iran

5. Hillen Brand, Robert, (2006). Islamic Art and Architecture. Translated by Ardeshir Eshraqi, Tehran: Rozaneh.

6. Mirjafari, Hossein (2000). History of political, social, economic and cultural changes of Iran during the Timurid and Turkmens. Tehran: SAMT.

7. Damand, Maurice Auson (2004). A guide to Islamic industries. Translated by Abdollah Faryar, Tehran: Elmi va Farhangi publication.

8. Pirnia, Karim, (2007). Stylistics of architecture in Iran. Edited by Gholam Hossein Memarian, Tehran: Soroush Danesh.

9. Goshayesh, Farhad (2000). The history of Art in Iran and the world. Tehran: Efaf.

10. Crandel, Ansisir, (2005). The history of art in Middle Ages. Translated by Hasan Afshar, Tehran: Markaz Publication.

11. Gardner, Helen. (1986). Art in the course of time. Translated by Mohammad Taghi Faramarzi, Tehran: Agah

12. Dornyei, Z. (2011). Transfiguration, beauty and biblical interpretation. England: University of Nottingham.

13. Vaziri, Ali Nagi (1984). General history of illustrated arts. Tehran: Hirmand. 


\section{Innovaciencia}

14. Braccons, Jose (2002). A guide to Gothic art. Translated by Sima Zolfaghari, Tehran: Saghi Publishing.

15. Anderson, Sh. (2003). The use of candle as a symbol in worship. CCWS and the author .

16. Vernikos, Fr. (2013). The Meaning Of The Use Of The Candle, The Incense And The Vigil Oil Lamp . Paracletos Greek Orthodox Monastery.

17. USCCB. (2007). Sing To The Lord: Music In Divine Worship. United States Conference Of Catholic Bishops.

18. Carli, E.(215). Siena Cathedral and The Cathedral Mu seum. Italy:Lito Terrazzi

19. Rafiee, Mahtab, Hasti Beshrootani and Parinaz Hosseini (2009). Selection of Iranian Art History. Tehran: Chaharsuye Honar 